\title{
The U.S. military culture system of values mirrored by professional lingo
}

\author{
Alexander Romanov ${ }^{1}$, Sergey Stepanov ${ }^{1}$, Marina Poluboyarova ${ }^{1,2}$, Mariya Angaleva ${ }^{1}$, and \\ Natalya Belaya ${ }^{1}$ \\ ${ }^{1}$ Russia's MOD Military University, Bolshaya Sadovaya Str., 14, 123001 Moscow, Russia \\ ${ }^{2}$ The Maurice Thorez Institute of Foreign Languages, Ostojenka Str., 38, B.1, 119034 Moscow, \\ Russia
}

\begin{abstract}
This research unveils the nature of relations among such phenomena as "ethnos", "culture" and "language". Vested with the function of axiological retranslation, mottoes of the U.S. Armed Forces services and branches make essential part of the military lingo as a semi-autonomous existential form of the national language. Clichéd formulas of the professional sublanguage official register explicitly reflect collective mindset, dominant values, behavioral patterns, and conceptosphere of America's society military cluster. The authors arrive at the conclusion that military mottoes are typical of vocativity, brevity, metaphoricity, widespread use of Latinisms, stereotypogenicity, and appeal for professional ethos.
\end{abstract}

\section{Introduction}

This paper belongs to the anthropocentric paradigm of studies and dwells on the phenomenon of stereotyping in the social context of the U.S. military culture. It focuses on the axiometric analysis of professional American warrior lingo, more precisely its official register.

The system of values serves as the moral and ethical bedrock for the military professional world image. There is no denying the fact that "camouflaged world" axiosphere is unique and has both object-material and sign-symbolic forms of expression. The world of values of the military is examined and interpreted through cultural phenomena. It is the language that reveals clandestine axiological niches and hidden motives of linguistic consciousness.

To examine social stereotypes through the professional system of values, the authors of this research appeal to an abstract theoretical tool. In this regard, we are talking about a collective identity of $G I$. It is assumed that a typical representative of the warrior environment abides by a specific moral code, lives in line with professionally shaped set of values, and has a distinctive "linguistic passport". Based on the given assumption, the authors conclude that a typical $G I$ is associated with certain social stereotypes.

Stereotype is a product of collective consciousness, shaped by someone else's practical experience. Social stereotypes of a certain professional community are closely intertwined with values. American soldiery lingo and its distinct phenomena pave the way to the world of values of military culture. Professionally marked stereotypes portray moral and psychological image of the GI collective identity. We would like to emphasize that in our study, 
the initial - type acronym of $G I$ is interpreted broadly. This term is generic for narrowly specialized lexemes of soldier, sailor, marine, airman, coast guardsman, and guardian. The lexemes given denote belonging to a certain branch of the U.S. Armed Forces (Army, Air Force, Navy, Marine Corps, Coast Guard, and Space Force). Following G.A. Sudzilovsky (1973), P. Dickson (2003), A. Axelrod (2013), G. Brown (2015), the precedent name GI Joe is associated with an imagery character, an average representative of the U.S. military culture. This generic name was most frequently used in relation to equipment and uniforms of the rank-and-file soldiers. The precedent name goes back to the jocular opinion that the social institute of violence is a product of the state machine [1], [2].

As T.E. Murray rightly points out, the tendency to linguistic creativity is characteristic of representatives of all branches of the armed forces. Soldiers, sailors, marines, and pilots create a special culture. Members of such a vitally important social community are bound together by a specific collective consciousness, nature of life conditions and social function of soldiery, values, and a distinctive lingo of the military service [3].

Stereotypes about the U.S. Army and its servicemen and women are explicated in the distinctive linguistic phenomena of the military sublanguage. The authors of this study define military lingo as a lexical subsystem addressing communicative needs of the military cluster of society. It has phonetic, grammar and, mostly, lexical peculiarities. The military sublanguage has two functional registers, namely official and unofficial ones. Varieties of the military lingo correspond to literary standard and the sociolect substandard.

V.P. Korovushkin notes that the normative and substandard varieties of the military lingo are intertwined conceptually and functionally. The literary standard register comprises military - specific notions and terminology. Vernacular substandard variety includes socio- professional and socio - corporate jargons, which can be ethnicized and localized [4]. The GI professional image of the world relies on a number of unique concepts, realities, and competencies necessary for successful military service. The speech of military personnel is closely related to specifics of military service, combat experience, and military technical terminology. The use of military vocabulary and terminology makes it possible to distinguish the professional group of servicemen from other social groups.

Linguistic interaction is a continuum of communication fields, which coincide with spheres of social links and labor. In various communicative situations people make use of various "linguistic passports" meeting requirements of their conversation [5]. One of such lexical subsystems of the national language is the military sublanguage. We fully share B.L. Boyko's point of view that socio-group dialects serve as a means of socially marked communication. Military sublanguage is a verbal instrument "to demonstrate belonging to a social group, to express its distinctiveness, separateness, and opposition to other social groups" [Ibid.].

The official register of the military lingo has normative-legal status, expresses corporate interests of the social institution of the armed forces, its professional values, needs, and expectations. The linguistic variant of the official discourse of servicemen represents the outer contour of communicative usage. The literary standard variety is used both for intragroup and intergroup communication. The bureaucratic variety of the military sublanguage exists mainly in a written form and produces declarative-rhetorical phenomena [6]. The latter include:

- lexical units (officially declared values of the Armed Forces branches);

- word-combinations (official mottoes and special historical names of military formations, and recruitment slogans);

- discursive units (texts of executive documents, military regulations and manuals, directives, instructions and reports, the military oath, professional ethos, creeds of the Armed Forces branches, etc.) [7] (Figure 1). 


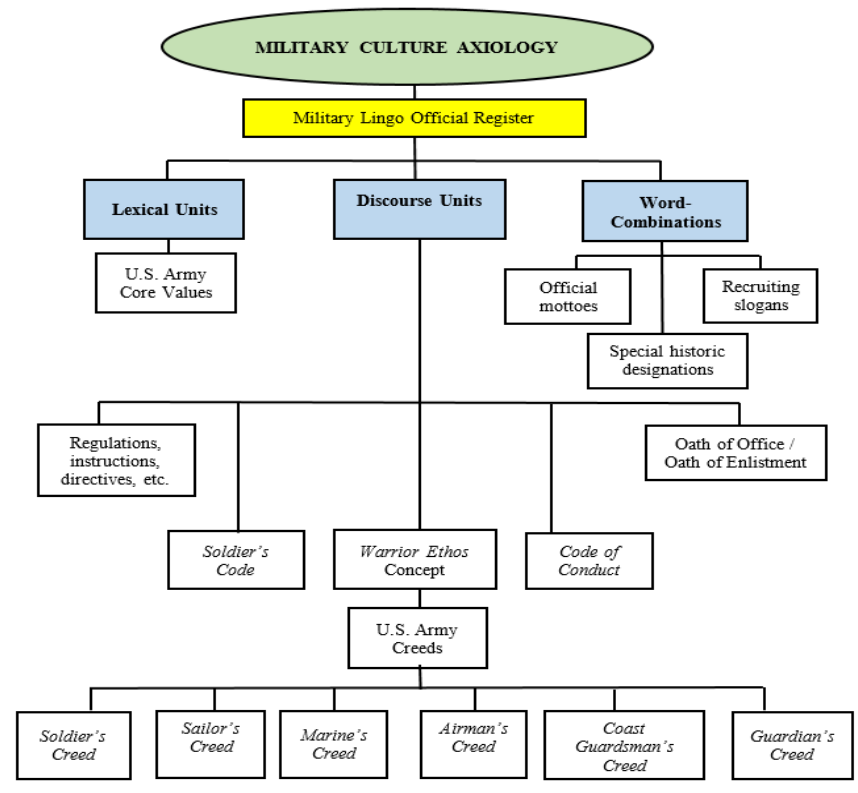

Fig. 1. Professional system of values reflected in military lingo official register.

\section{Materials and Methods}

V.P. Korovushkin's contrastive sociolect concept (2005), B.L. Boyko's theory of socio-group dialectology (2008), and A.S. Romanov's axio- stereotypical concept (2020) serve as a theoretical foundation for our research.

The subject area of this study is the official mottoes of the U.S. Armed Forces branches, units and formations. Mottoes reflect the axiological core of the socio-professional milieu of the military. As a linguistic phenomenon the motto belongs to the official register of the military lingo and serves a productive linguistic means to express military-specific values. The purpose of this study is to examine moral and ethical imperatives of the U.S. military culture of $G I$ on the material of clichéd speech formulas. This research has been exemplified in English based on the analytical-descriptive method, the method of continuous sampling of illustrative material, elements of intentional and contextual analysis.

Illustrative material is extracted from official U.S. DoD online resources (www.army.mil, www.navy.mil, www.marines.mil, www.marines.com, www.airforce.com, www.af.mil, www.uscg.mil, www.jcs.mil, www.defense.gov), unofficial websites, related publications, and specialized lexicographic sources (Stein, 1993; Martin, 2012; Shevchuk, 2016). A total of about 200 official mottoes of U.S. Armed Forces combat services and branches have been examined. 22 Army mottoes are given as an example for key axiological concepts of the military culture (Table 1).

Table 1. Official mottoes and core values of the U.S. Armed Forces branches

\begin{tabular}{|l|c|c|l|}
\hline $\begin{array}{c}\text { U.S. Armed } \\
\text { Forces branches }\end{array}$ & Birth date & Official motto & Core values \\
\hline Army & June 14, 1775 & This we'll defend & $\begin{array}{l}\text { Loyalty, duty, respect, selfless service, } \\
\text { honor, integrity, and personal courage }\end{array}$ \\
\hline Navy & October 13,1775 & $\begin{array}{c}\text { Always Strong } \\
\text { (Semper Fortis) }\end{array}$ & Honor, courage, and commitment \\
\hline Marine Corps & $\begin{array}{c}\text { November 10, } \\
1775\end{array}$ & $\begin{array}{c}\text { Always Faithful } \\
\text { (Semper Fidelis / Fi) }\end{array}$ & Honor, courage, and commitment
\end{tabular}


Table 1. Continued.

\begin{tabular}{|l|c|c|l|}
$\begin{array}{c}\text { U.S. Armed } \\
\text { Forces branches }\end{array}$ & Birth date & Official motto & \multicolumn{1}{|c|}{ Core values } \\
\hline Air Force & September 18, & $\begin{array}{c}\text { Aim High... } \\
\text { Fly-Fight-Win }\end{array}$ & $\begin{array}{l}\text { Integrity first, service before self, and } \\
\text { excellence in all we do }\end{array}$ \\
\hline Coast Guard & August 4,1790 & $\begin{array}{c}\text { Always Ready } \\
\text { (Semper Paratus) }\end{array}$ & Honor, respect, and devotion to duty \\
\hline Space Force & $\begin{array}{c}\text { December 20, } \\
2019\end{array}$ & $\begin{array}{c}\text { Always Above } \\
\text { (Semper Supra) }\end{array}$ & $\begin{array}{l}\text { Integrity first, service before self, and } \\
\text { excellence in all we do }\end{array}$ \\
\hline
\end{tabular}

\section{Results and Discussion}

At present, the organizational structure of the U.S. Armed Forces is represented by six independent branches: Army, Navy, Air Force, Marine Corps, Coast Guard and, most recently, Space Force. The National Guard has the status of an organized reserve for the Army and the Air Force. The military professional lingo is a rich palette with a special role given to set expressions or speech formulas. The latter is fully applicable to official mottoes of U.S. military branches, their units and formations. An army motto can be defined as a specific form of speech cliché. Military mottoes are extra - personal and have a high degree of vernacular frequency in the professional communicative environment [8].

A military motto is nothing other than a manifestation of the military culture, embodied in signs of language. Mottoes of regular Army combat units (divisions, separate brigades, and regiments), which explicate the $G I$ system of value orientations, are cited as illustrations below (Table 2).

The semantic core of the U.S. Army combat formations, imbued with the spirit of selfdenial for the sake of national prosperity and common good, can be interpreted as follows: military service is the greatest honor and supreme display of loyalty and love for the Fatherland.

It is noteworthy that clichéd speech formulas are characterized by the widespread use of the Latin language. On the one hand, the use of Latin is indicative of the high-flown style of the military lingo official register. On the other hand, Latin signifies affiliation with sacred religious traditions and values deep-rooted in Christian culture. Consider, for instance, such mottoes as Semper Primus (1st Infantry Regiment), Patriae Fidelitas (8th Infantry Regiment), Exempla Proponere (11 Aviation Battalion), Ad Excelsum Conamur (12 Aviation Group), Nihil Obstat (557th Artillery Group), Spina Frontis (559th Artillery Group), etc.

The connotative component of military mottoes appeals to the cultural and historical heritage of the GI socio-professional group. It requires an explicit disclosure of the system of meanings that remain unseen and obscure for those uninitiated.

Table 2. U.S. Army branches mottoes and fundamental values.

\begin{tabular}{|c|c|c|c|c|}
\hline $\begin{array}{c}\text { Armed } \\
\text { service and } \\
\text { branch }\end{array}$ & No & Military unit & Official motto & Key concepts \\
\hline & 1 & $\begin{array}{c}\text { 82nd Airborne } \\
\text { Division }\end{array}$ & $\begin{array}{c}\text { All the Way! / Death } \\
\text { from Above }\end{array}$ & Firmness, military might \\
\cline { 2 - 5 } Army / & 2 & $\begin{array}{c}\text { 101st Airborne } \\
\text { Division }\end{array}$ & $\begin{array}{c}\text { Rendezvous with } \\
\text { Destiny } \\
\text { (Ne desit Virtus) }\end{array}$ & Military service danger, sacrifice \\
\cline { 2 - 5 } & 3 & $\begin{array}{c}\text { 173rd Airborne } \\
\text { Birborne }\end{array}$ & $\begin{array}{c}\text { If not US, Who? If } \\
\text { not Now, When? / } \\
\text { Sky Soldiers }\end{array}$ & Devine mission, call of duty \\
\cline { 2 - 5 } & 4 & $\begin{array}{c}\text { 118th Military Police } \\
\text { Company (ABN) }\end{array}$ & $\begin{array}{c}\text { Heaven Sent, Hell } \\
\text { Bent! The Mighty } \\
\text { Mighty }\end{array}$ & Devine mission, military might \\
\cline { 2 - 5 } & & \multicolumn{2}{|c}{} & \\
\hline
\end{tabular}


Table 2. Continued.

\begin{tabular}{|c|c|c|c|c|}
\hline \multirow{4}{*}{$\begin{array}{l}\text { Army / } \\
\text { Armored }\end{array}$} & 5 & $\begin{array}{l}\text { 1st Armored } \\
\text { Division }\end{array}$ & Iron soldiers! & Firmness and stamina \\
\hline & 6 & $\begin{array}{l}\text { 2nd Armored } \\
\text { Division }\end{array}$ & Hell on Wheels & Military might \\
\hline & 7 & $\begin{array}{l}\text { 13th Armored } \\
\text { Division }\end{array}$ & It Shall Be Done & Mission fulfillment \\
\hline & 8 & $\begin{array}{c}\text { 32nd Armored } \\
\text { Regiment }\end{array}$ & Victory or Death & Selfless service and sacrifice \\
\hline \multirow[t]{4}{*}{$\begin{array}{l}\text { Army / } \\
\text { Infantry }\end{array}$} & 9 & 1st Infantry Division & $\begin{array}{c}\text { No Mission Too } \\
\text { Difficult, No } \\
\text { Sacrifice Too Great } \\
\text { - Mission First!, } \\
\text { Duty First, First to } \\
\text { Fight } \\
\end{array}$ & $\begin{array}{l}\text { Mission fulfillment, selfless } \\
\text { service and sacrifice, duty }\end{array}$ \\
\hline & 10 & 4th Infantry Division & Steadfast and Loyal & Firmness and loyalty \\
\hline & 11 & 7th Infantry Division & $\begin{array}{c}\text { Light, Silent, and } \\
\text { Deadly }\end{array}$ & Military might \\
\hline & 12 & $\begin{array}{c}\text { 2nd Cavalry } \\
\text { Regiment }\end{array}$ & $\begin{array}{l}\text { Ready to Strike, } \\
\text { Anytime, Anywhere }\end{array}$ & $\begin{array}{c}\text { Instant combat readiness, military } \\
\text { might }\end{array}$ \\
\hline \multirow{4}{*}{$\begin{array}{l}\text { Army / } \\
\text { Artillery }\end{array}$} & 13 & $\begin{array}{l}\text { 320th Field Artillery } \\
\text { Regiment }\end{array}$ & $\begin{array}{l}\text { Willing and Able } \\
\text { (Volens et Potens) }\end{array}$ & Will, stamina and professionalism \\
\hline & 14 & $\begin{array}{c}\text { 143rd Field Artillery } \\
\text { Regiment }\end{array}$ & $\begin{array}{l}\text { Facta Non Verba } \\
\text { (Deeds, not Words) }\end{array}$ & Deeds of honour \\
\hline & 15 & $\begin{array}{c}\text { 434th Field Artillery } \\
\text { Brigade }\end{array}$ & Service with Pride & Pride \\
\hline & 16 & 512 Artillery Group & Valour About All & Valour \\
\hline \multirow{4}{*}{$\begin{array}{l}\text { Army / } \\
\text { Aviation }\end{array}$} & 17 & $\begin{array}{c}\text { 1st Aviation } \\
\text { Regiment }\end{array}$ & $\begin{array}{l}\text { Above the First } \\
\text { (Super Primum) }\end{array}$ & Exclusiveness, excellence \\
\hline & 18 & $\begin{array}{l}\text { 4th Aviation } \\
\text { Regiment }\end{array}$ & $\begin{array}{c}\text { Eternal Vigilance } \\
\text { (Vigilantia Aeterna) }\end{array}$ & Vigilance and combat readiness \\
\hline & 19 & $\begin{array}{l}\text { 3rd Aviation } \\
\text { Regiment }\end{array}$ & $\begin{array}{l}\text { We Fight on Wings } \\
\text { (Ex Alis Pugnamus) }\end{array}$ & Military might \\
\hline & 20 & $\begin{array}{l}\text { 21st Aviation } \\
\text { Battalion }\end{array}$ & "Peace and War" & Peace and war \\
\hline
\end{tabular}

\section{Conclusions}

An axiometric analysis of military mottoes makes it possible to objectify specifics of the military culture and its axiological dimension. Official mottoes of military units and formations reflect key values and uniqueness of the GI collective consciousness. Our study delivers a number of conclusions:

1. The warrior identity of GI is characterized by a distinctive worldview, professional lingo, system of values, symbols and rituals, traditions, and norms of verbal and non-verbal behavior;

2. Stereotypogenic potential of a certain linguistic unit is defined as a property to implicitly or explicitly express assessments, beliefs, and characteristics as necessarily accompanying a particular object of reality;

3. Military clichéd set expressions manifest the ideas of patriotism, duty, priority of combat mission, valor, and sacrifice of military service. In a lapidary form, mottoes convey a sense of cross-generational continuity, belonging to the history and traditions of the military;

4. Religious and historic motives are clearly traced in official manifestations of military units. 
5. Invocatory character, brevity, metaphoricity, extensive use of Latinisms, stereotypogenic potential, and appeal for supreme professional values of warrior's ethos are among distinctive features of military mottoes.

\section{References}

1. G. A. Sudzilovsky, Slang - what is it? The English Prolific Military Vocabulary, 121 (1973)

2. P. Dickson, War Slang: America fighting words and phrases since the Civil, 179, 314 (2003)

3. T. E. Murray, American speech, 61(2), 125 (1986)

4. V. P. Korovushkin, Fundamentals of Contrastive Sociolectology, 2, 130 (2005)

5. B. L. Boyko, Social and group dialectology, 18, 20 (2018)

6. A. S. Romanov, Subcultural constants stereotyping through the axiology of the sociogroup dialect (as exemplified by the military service values and realities of the U.S. linguoculture), 18 (2020)

7. A. S. Romanov, Subcultural constants stereotyping through the axiology of the sociogroup dialect (as exemplified by the military service values and realities of the U.S. linguoculture), 13 (2020)

8. A. S. Romanov, Voprosy psycholinguistics, 3(33), 124 (2017)

9. A. S. Romanov, Ethnic Stereotypes of the U.S. military subculture as reflected by language and culture, 85 (2017)

10. B. J. Stein, U.S., Army Heraldic Crests: A Complete Illustrated History of Authorized Distinctive Unit Insignia (1993)

11. M. W. Martin, Of Mottos and Morals: Simple Words for Complex Virtues (2012)

12. V. N. Shevchuk, Handbook of the Military Translator (2016) 